\title{
Industrial Scale Ammonia Pipeline Transfer System and Exergy Analysis
}

\author{
A. O. Gezerman*
}

Toros Agri \& Industry, Research \& Development Center, Mersin, Turkey

\begin{abstract}
Anhydrous ammonia is the most used raw material in chemical fertilizer production. In the fertilizer production process, during the transportation of anhydrous ammonia, pressure and temperature have to be kept under control. Transport and storage of anhydrous ammonia requires resistance to cryogenic conditions. Therefore, materials that are resistant to cryogenic conditions are preferred for the transport of ammonia.

In this study, the kinetic energy of anhydrous ammonia transported under cryogenic conditions $\left(-33^{\circ} \mathrm{C}\right)$ was analysed and solutions proposed to minimize the problems such as cracking and corrosion occurring in the materials that form the structure of transportation and storage systems due to cryogenic conditions were discussed.
\end{abstract}

\section{Keywords}

Ammonia, cryogenic conditions, multistage compressor, manifold

\section{Introduction}

One of the most important raw materials in chemical fertilizer production is anhydrous ammonia. In the fertilizer production process, anhydrous ammonia is used by conditioning $\left(>10{ }^{\circ} \mathrm{C}, 6 \mathrm{bar}\right)$. This conditioning process is usually carried out by evaporating ammonia through evaporators. Therefore, the storage of ammonia to be used in the chemical fertilizer production process is a sensitive issue, and due to the low boiling point of ammonia $\left(-33^{\circ} \mathrm{C}\right)$, it has to be brought to the desired conditions with the use of multi-stage compressors and expansion valves.

The cryogenic and abrasive properties of anhydrous ammonia, which is used as a raw material in chemical fertilizer production, require the material to be used as process building material to have certain properties. Because the corrosive nature of ammonia causes metal wear in the process in which it is used, it may cause metal contamination in the final product.

In order to avoid problems such as metal contamination, materials that are not affected by the corrosive properties of ammonia should be used in the process. However, volumetric changes that may occur in the process lines due to cryogenic conditions cause the metal structure that forms the lines of the process to wear out. Since both anhydrous ammonia storage and chemical fertilizer production facilities require high investments, problems such as corrosion and abrasion in the process lines should be minimized.

The design of ammonia pipelines is an important focus of researchers. One of the first design studies on this subject was carried out by Roasch et al. ${ }^{1}$ Similarly, important studies have been carried out on land and sea transportation for ammonia transportation within the United States. ${ }^{2}$

\footnotetext{
*Ahmet Ozan Gezerman, PhD

Email: ozan.gezerman@toros.com.tr
}

There are also various field studies on industrial scale storage of ammonia. ${ }^{3}$ The use of pressure injection systems for the storage of ammonia is one of the first studies in this direction. ${ }^{4}$ In such a study, semi-cooled spherical tanks were used for the storage of ammonia. ${ }^{5}$ On the other hand, the risks associated with transporting ammonia by wagons, barges and pipelines are reported in the literature. ${ }^{6}$

In order to reduce the problems that may occur during the transport of ammonia, semi-cooling systems have been studied. ${ }^{7}$ In a study similar to this, it was found that the transportation of petroleum-derived chemicals differs significantly in terms of long-term use of the lines. ${ }^{8}$

In another study on the transportation of ammonia by long pipelines, prevention of ammonia leaks by providing insulation in the pipeline of crude oil was evaluated. ${ }^{9}$

In addition, atmospheric pressure storage and transportation of ammonia is another example that can be given to the relevant isolation studies. Such a facility can be developed to include condensation tower, saturation tower, and ventilation equipment in itself. There are studies on volume changes in such a facility due to cryogenic conditions. $^{10}$

There are also various research studies on the methods of removing dissolved metal salts from the environment during the storage and transfer of anhydrous ammonia. ${ }^{11}$ Similar to the transport of ammonia for storage, various methods have been developed for transferring it for use in agricultural fields, such as manifolds. ${ }^{12}$

Another method of transporting anhydrous ammonia is the use of underground pipes. ${ }^{13} \mathrm{~A}$ similar research study involves the use of transfer lines to transport ammonia to agricultural areas. ${ }^{14}$ However, other petroleum-derived chemicals such as ammonia were carried on the same transfer line. ${ }^{15}$ 
There are also reported studies on the transport of ammonia and the cleaning of process pipelines in various ways using inert gases and the thermodynamic behaviour of ammonia. ${ }^{16-18}$ Considering the volume changes that may occur in the lines where ammonia is transported, as well as the environmental risks involved in the transportation of ammonia are important issues studied. ${ }^{19,20}$

In the literature, the number of loops used to reduce the problems caused by sudden volume changes during the ammonia transfer and their exergy analysis have not been reported on an industrial scale. In this study, the sections named "loop" used against sudden volume changes during ammonia transfer on an industrial scale were defined, and an exergy analysis was made by calculating the number of loops to be used on the pipeline.

\section{Ammonia storage systems and methodology}

In the design of ammonia pipelines, it is necessary to anticipate possible sudden volume changes due to the cryogenic properties of ammonia. To accommodate these volume changes, pipelines have to be built longer than they should be. Length caused by volume changes can be tolerated by creating " $U$ " shaped sections on the pipeline. These " $U$ " shaped sections are called loops (Fig. 1).

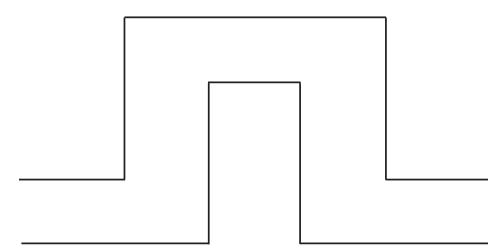

Fig. 1 - Shape change occurring in the ammonia pipeline

Pressure losses occurring in the transfer line due to the low boiling point of ammonia were formulated by Darcy-Weisbach. ${ }^{21}$

$$
\Delta P=f_{p} \frac{V^{2} L}{2 D_{i}}=f \frac{L \dot{m}^{2}}{\pi^{2} \rho D_{i}^{5}}
$$

As may be seen, at a defined flow, the pressure loss is inversely proportional to the fifth force of the pipe diameter. Using the current Blasius correlation for turbulent flow in smooth pipe with $\operatorname{Re}=D_{i} V / v$ and $V=4 m / \pi \rho D_{i}^{2}$, the friction factor known as $f=0.3614 / \operatorname{Re}^{0.25}$ can be written as:

$$
f=\frac{0.224 \pi^{0.25} \mu^{0.25}}{\dot{m}^{0.25}}
$$

\section{Results and discussion}

The use of anhydrous ammonia as an important raw material in chemical fertilizer production has necessitated the development of ammonia transfer lines. The distance of ammonia production facilities to industrial facilities where it is used as raw material is another important reason for the development of lines used for ammonia transport. The cryogenic properties of ammonia form the basis of transfer studies.

Transporting anhydrous ammonia may require different ways of handling the material to behave flexibly. During the transfer of anhydrous ammonia, it must be kept in a liquid state and at a constant flow temperature, and also the pressure value must be maintained. Because ammonia has a low boiling point $\left(-33^{\circ} \mathrm{C}\right)$, it creates an additional pressure in the pipelines during transfer. This pressure poses a problem for the long-term use of transfer lines. In order to maintain pressure balance in transfer lines, water tanks are placed in the pipeline at certain distances and excess ammonia is removed from the system by the adsorption mechanism.

\subsection{Optimum pipe diameter}

The enthalpy value of liquid and gaseous states in the ammonia $L$-length transfer line and the thermal change occurring during this time can be expressed as follows: ${ }^{20}$

$$
\dot{Q}=\frac{\dot{q}_{r l}}{\rho\left(h_{\text {vap }}-h_{\text {liq }}\right)}
$$

In such a case, the cost of maintenance of the welded pipe due to material wear caused by cryogenic conditions in the line can be expressed as follows:

$$
\begin{aligned}
C_{\text {total }}= & \frac{1.79 \mu^{0.25} L}{\pi^{1.75} \rho^{2} D_{i}^{4.75}} \frac{q_{r l}^{2.75}}{\left(h_{\text {vap }}-h_{\text {liq }}\right)^{2.75}} \frac{1}{\eta_{s} \eta_{m}} C_{\mathrm{e}} t_{\text {an }}+ \\
& +L \frac{\pi\left(\delta^{2}-1\right) D_{i}^{2} C_{\text {mat }} \rho_{\text {mat }}}{4} \text { DF }
\end{aligned}
$$

Thus, the optimum pipe diameter for an industrial cooling line can be calculated as follows:

With a general acceptance

$$
\frac{\mathrm{d} C_{\text {total }}}{\mathrm{d} D_{i}}=0
$$

Assuming that the optimum pipe diameter is,

$D_{i, \text { opt }}=\left(\sqrt[6.75]{\frac{0.714 C_{\mathrm{e}} t_{\mathrm{an}}}{\left(\delta^{2}-1\right) C_{\mathrm{mat}} \rho_{\mathrm{mat}} \mathrm{CRF}}}\right)\left(\sqrt[6.75]{\frac{\mu^{0.25} \dot{q}_{\mathrm{rl}}^{2.75}}{q_{\mathrm{ref}}^{2}\left(h_{\mathrm{vap}}-h_{\mathrm{liq}}\right)^{2.75} \eta_{s} \eta_{m}}}\right)$

In this equation, the first expression in brackets is related to the economy of the pipe, while the expression in the other brackets expresses the effect of the thermal changes 
that occur during the ammonia transfer on the pipe mechanism.

Table 1 - Characterization of the pipeline for ammonia transfer under cryogenic conditions

\begin{tabular}{l|c|c|c}
\hline Parameter & Symbol & $\begin{array}{c}\text { Characterization } \\
\text { of pipe for } \\
\text { cryogenic } \\
\text { conditions }\end{array}$ & $\begin{array}{c}\text { Characterization } \\
\text { for the initial } \\
\text { state of the pipe }\end{array}$ \\
\hline heat flux $/ \mathrm{W} \mathrm{m}^{-2}$ & $\dot{Q}$ & 200 & 200 \\
\hline $\begin{array}{l}\text { heat conduction } \\
\text { coefficient } / \mathrm{W} \mathrm{mK}^{-1}\end{array}$ & $k$ & 508 & 508 \\
\hline outer radius $/ \mathrm{mm}$ & $r_{2}$ & 497 & 497 \\
\hline $\begin{array}{l}\text { inner radius } / \mathrm{mm} \\
\text { pipe length } / \mathrm{m}\end{array}$ & $r_{1}$ & $L_{1}$ & $L_{2}$ \\
\hline $\begin{array}{l}\text { internal } \\
\text { temperature } / \mathrm{K}\end{array}$ & $T_{1}$ & 240 & 240 \\
\hline $\begin{array}{l}\text { outside } \\
\text { temperature } / \mathrm{K}\end{array}$ & $T_{2}$ & 313 & 313 \\
\hline $\begin{array}{l}\text { surface area } \\
\text { where heat is } \\
\text { transferred } / \mathrm{m}^{2}\end{array}$ & $A$ & $2 \pi r L$ & $2 \pi r L$ \\
\hline
\end{tabular}

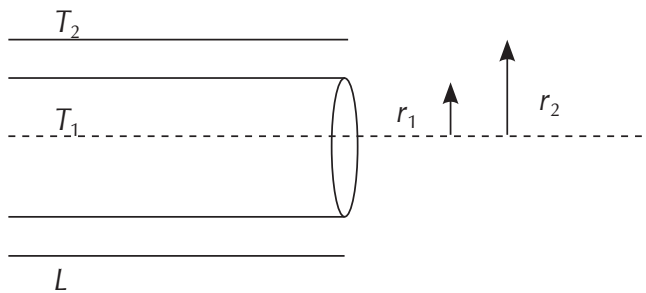

Fig. 2 - Cylindrical cross-sectional area in an ammonia pipeline

According to the Fourier law (conduction heat transfer):

$$
Q=-k \cdot A \cdot \frac{\mathrm{d} T}{\mathrm{~d} r}
$$

Mathematical expression of the equation:

$$
\int \frac{Q \mathrm{~d} r}{k 2 \pi r L}=\int \mathrm{d} T
$$

If the equation is analysed for the first case determined (Table 1, Fig. 2);

$$
\begin{gathered}
Q \frac{\left(\ln r_{2}\right)-\left(\ln r_{1}\right)}{(k 2 \pi r L)}=\left(T_{1}-T_{2}\right) \\
r_{2}=20 \cdot 2.54 \cdot 10=508 \mathrm{~mm} \\
\ln 508=6.23
\end{gathered}
$$

$$
r_{1}=508-11=497 \mathrm{~mm}
$$

(11 $\mathrm{mm}$ wall thickness of the pipe)

$$
\begin{gathered}
\ln 497=6.20 \\
T_{1}=-33{ }^{\circ} \mathrm{C}=240 \mathrm{~K} \\
T_{2}=40{ }^{\circ} \mathrm{C}=313 \mathrm{~K}
\end{gathered}
$$

Heat flux is calculated according to Eq. (9). When $L$ is drawn from this equation

$$
L=Q \frac{\left(\ln r_{2}\right)-\left(\ln r_{1}\right)}{(k 2 \pi r)\left(T_{1}-T_{2}\right)}
$$

Considering the pipe length $L_{1}$ of $40{ }^{\circ} \mathrm{C}(313 \mathrm{~K})$ in the first case, and the pipe length $L_{2}$ at a temperature of $-33{ }^{\circ} \mathrm{C}$ $(240 \mathrm{~K})$ in the second case, it is necessary to put a loop inside the pipe to compensate for the volume loss due to cryogenic conditions. In this case, from Eq. (8) it comes:

$$
\begin{gathered}
Q \frac{\ln r}{r k 2 \pi r L}=T \\
Q \frac{\ln r}{r k 2 \pi r T}=L \\
Q \frac{\ln r_{40^{\circ} \mathrm{C}}}{r_{40^{\circ} \mathrm{C}} 2 \pi r T_{40^{\circ} \mathrm{C}}}=L_{40^{\circ} \mathrm{C}} \\
\frac{\ln r_{-33^{\circ} \mathrm{C}}}{r_{-33^{\circ} \mathrm{C}} 2 \pi r T_{-33^{\circ} \mathrm{C}}}=L_{-33^{\circ} \mathrm{C}}
\end{gathered}
$$$$
\text { For } 40{ }^{\circ} \mathrm{C}
$$$$
\text { For }-33^{\circ} \mathrm{C}
$$

The ratio of the length values found for these two temperature values will give the volumetric loss, and therefore the number of loops required in the transfer line.

$$
\begin{gathered}
\frac{Q \frac{\ln r_{40^{\circ} \mathrm{C}}}{r_{40^{\circ} \mathrm{C}} 2 \pi k T_{40^{\circ} \mathrm{C}}}}{\frac{\ln r_{-33^{\circ} \mathrm{C}}}{r_{-33^{\circ} \mathrm{C}} 2 \pi k T_{-33^{\circ} \mathrm{C}}}}=\frac{L_{40^{\circ} \mathrm{C}}}{L_{-33^{\circ} \mathrm{C}}} \\
\frac{\operatorname{Qn} \frac{\ln 508}{508 \mathrm{~mm} \cdot 2 \pi \cdot k(273+40) \mathrm{K}}}{Q \frac{\ln 497}{497 \mathrm{~mm} \cdot 2 \pi \cdot k(273-33) \mathrm{K}}}=\frac{L_{-33^{\circ} \mathrm{C}}}{L_{40^{\circ} \mathrm{C}}} \\
\frac{L_{40^{\circ} \mathrm{C}}}{L_{-33^{\circ} \mathrm{C}}}=1.28
\end{gathered}
$$

If an assumption is made for weather conditions up to $40{ }^{\circ} \mathrm{C}$ according to summer season conditions; when the maximum volumetric loss value that may occur in the pipeline is taken as reference, a volume loss of 1.28 times the length of the first pipeline will occur.

Accordingly, at the planned distances of the ammonia pipeline with the aforementioned pipe diameters, the number of "loops" to be applied to the line can be determined by considering the 1.28 ratio calculated for volumetric changes that may occur in the pipeline. 
For example, $100 \mathrm{~m}$ of pipeline under atmospheric conditions should be taken as $128 \mathrm{~m}$ at $-33{ }^{\circ} \mathrm{C}$. In this way, loops should be formed from the remaining $28 \mathrm{~m}$ in the system. These loops on the pipeline can be prepared at different heights according to the shape of the road. For example, by making 4 loops $7 \mathrm{~m}$ high or 7 loops $4 \mathrm{~m}$ high, volumetric changes in the line due to the cryogenic environment can be avoided.

\subsection{Material selection for cryogenic conditions}

The use of industrial materials to transport supercooled (cryogenic) materials requires certain conditions. Corrosion risk of pipe transfer lines is an important problem due to the corrosive properties of the transferred chemical. Materials such as copper, zinc, and aluminum, which are frequently used in industrial process lines, carry a risk of corrosion due to the corrosive nature of ammonia. For this reason, steel materials that are not affected by the corrosive nature of ammonia are used in ammonia transfer lines. In addition, steel material can be used as building material for all kinds of cooling materials. However, the use of steel pipes in large diameters can be more economical.

In ammonia applications, thicker-walled Type 80 is preferred among steel pipes, which are industrially called Types 40 and 80 . The pipeline used for ammonia transfer should made out of steel material due to cryogenic conditions involved. The pressure differences of the steel material at different evaporation temperatures and different pipe diameters are shown in Table 2.

Multi-stage compressors are used to liquefy ammonia ${ }^{22}$ at high pressure (17 bar). ${ }^{23}$ Liquefaction operation at this pressure value cannot be performed in single-stage compressors. However, the use of multi-stage compressors for compression under high pressure is preferred to compensate for pressure losses in the transfer of ammonia. ${ }^{24}$

In the ammonia liquefaction process, a multi-stage compressor provides the cryonic ambient conditions $\left(-33^{\circ} \mathrm{C}\right.$, $17 \mathrm{bar})$, and the liquefied ammonia is circulated in all transfer lines. The low boiling point of ammonia and its constant tendency to evaporate cause pressure differences along the transfer lines. Accordingly, thermal and volumetric changes, material erosion and thus material cracking may occur within the transfer line. Therefore, in an exergy analysis made due to these changes in ammonia transfer, the thermal change in the line length $L$ can be expressed as follows;

$$
\dot{Q}_{L}=\dot{m}(1-x)\left(h_{1}-h_{2}\right)
$$

where $x$ is expressed as the ratio of the mass of gaseous ammonia to the total amount of ammonia in the transfer line. Similarly, $h_{1}$ is the enthalpy value of ammonia in gas phase, and $h_{2}$ is the enthalpy value of ammonia in liquid phase, indicates the mass flow rate of the total ammonia used in this system.

Accordingly, considering the energy losses in the lines and the work done by the compressor during the transfer for the exergy analysis (Fig. 3)
Table 2 - Steel material optimum capacities (kW) and possible pressure losses $\left(\mathrm{Pa} \mathrm{m}^{-1}\right)$ for ammonia transfer

\begin{tabular}{|c|c|c|c|c|c|}
\hline \multirow{2}{*}{$\begin{array}{l}\text { Type } 40 \text { steel } \\
\text { pipe } \\
\Delta p / \mathrm{Pa} \mathrm{m}^{-1}\end{array}$} & \multicolumn{5}{|c|}{ Evaporation temperature $/{ }^{\circ} \mathrm{C}$} \\
\hline & -35 & -25 & -15 & -5 & 5 \\
\hline $\begin{array}{c}3 / 8^{\prime \prime} \\
\Delta p\end{array}$ & $\begin{array}{c}0.87 \\
16.61\end{array}$ & $\begin{array}{c}1.30 \\
24.56\end{array}$ & $\begin{array}{c}2.02 \\
31.06\end{array}$ & $\begin{array}{c}2.6 \\
36.84\end{array}$ & $\begin{array}{c}3.75 \\
44.78\end{array}$ \\
\hline $\begin{array}{l}1 / 2^{\prime \prime} \\
\Delta p\end{array}$ & $\begin{array}{c}1.42 \\
13.72\end{array}$ & $\begin{array}{c}2.26 \\
21.67\end{array}$ & $\begin{array}{c}3.40 \\
26.72\end{array}$ & $\begin{array}{c}4.53 \\
32.50\end{array}$ & $\begin{array}{c}6.38 \\
39.00\end{array}$ \\
\hline $\begin{array}{l}3 / 4^{\prime \prime} \\
\Delta p\end{array}$ & $\begin{array}{c}2.19 \\
10.83\end{array}$ & $\begin{array}{c}3.62 \\
16.61\end{array}$ & $\begin{array}{c}5.30 \\
20.95\end{array}$ & $\begin{array}{c}7.11 \\
24.56\end{array}$ & $\begin{array}{c}10.1 \\
30.34\end{array}$ \\
\hline $\begin{array}{l}1^{\prime \prime} \\
\Delta p\end{array}$ & $\begin{array}{c}3.66 \\
9.390\end{array}$ & $\begin{array}{c}6.17 \\
14.45\end{array}$ & $\begin{array}{c}8.95 \\
18.06 \\
\end{array}$ & $\begin{array}{c}12.0 \\
21.67\end{array}$ & $\begin{array}{c}17.0 \\
26.00\end{array}$ \\
\hline $\begin{array}{l}2^{\prime \prime} \\
\Delta p\end{array}$ & $\begin{array}{c}9.89 \\
2.889\end{array}$ & $\begin{array}{l}16.3 \\
5.056\end{array}$ & $\begin{array}{c}23.7 \\
5.778\end{array}$ & $\begin{array}{c}31.8 \\
7.223\end{array}$ & $\begin{array}{c}45.4 \\
8.667\end{array}$ \\
\hline $\begin{array}{c}21 / 2^{\prime \prime} \\
\Delta p\end{array}$ & $\begin{array}{c}21.6 \\
5.056\end{array}$ & $\begin{array}{c}35.7 \\
7.945\end{array}$ & $\begin{array}{l}51.9 \\
9.390\end{array}$ & $\begin{array}{c}69.6 \\
11.56\end{array}$ & $\begin{array}{c}99.4 \\
13.72\end{array}$ \\
\hline $\begin{array}{l}3^{\prime \prime} \\
\Delta p\end{array}$ & $\begin{array}{c}33.1 \\
4.334 \\
\end{array}$ & $\begin{array}{c}54.9 \\
6.500\end{array}$ & $\begin{array}{l}79.6 \\
7.945\end{array}$ & $\begin{array}{c}107 \\
9.390\end{array}$ & $\begin{array}{c}152 \\
11.56\end{array}$ \\
\hline $\begin{array}{c}31 / 2 " \\
\Delta p\end{array}$ & $\begin{array}{c}45.5 \\
3.611\end{array}$ & $\begin{array}{c}75.4 \\
5.778\end{array}$ & $\begin{array}{c}109 \\
7.223\end{array}$ & $\begin{array}{c}147 \\
7.945\end{array}$ & $\begin{array}{c}206 \\
10.11\end{array}$ \\
\hline $\begin{array}{l}4^{\prime \prime} \\
\Delta p\end{array}$ & $\begin{array}{c}57.4 \\
3.611\end{array}$ & $\begin{array}{c}95.0 \\
5.056\end{array}$ & $\begin{array}{c}138 \\
6.500\end{array}$ & $\begin{array}{c}185 \\
7.223\end{array}$ & $\begin{array}{c}264 \\
9.390\end{array}$ \\
\hline $\begin{array}{l}5^{\prime \prime} \\
\Delta p\end{array}$ & $\begin{array}{c}91.8 \\
2.890\end{array}$ & $\begin{array}{c}152 \\
4.334\end{array}$ & $\begin{array}{c}221 \\
5.056\end{array}$ & $\begin{array}{c}296 \\
6.500\end{array}$ & $\begin{array}{c}422 \\
7.945\end{array}$ \\
\hline $\begin{array}{l}6^{\prime \prime} \\
\Delta p\end{array}$ & $\begin{array}{c}136 \\
2.167\end{array}$ & $\begin{array}{c}225 \\
3.611 \\
\end{array}$ & $\begin{array}{c}326 \\
4.334 \\
\end{array}$ & $\begin{array}{c}438 \\
5.056\end{array}$ & $\begin{array}{c}625 \\
6.500\end{array}$ \\
\hline $\begin{array}{l}8^{\prime \prime} \\
\Delta p\end{array}$ & $\begin{array}{c}250 \\
2.167\end{array}$ & $\begin{array}{c}414 \\
2.890\end{array}$ & $\begin{array}{c}601 \\
3.611\end{array}$ & $\begin{array}{c}806 \\
4.334\end{array}$ & $\begin{array}{l}1150 \\
5.778\end{array}$ \\
\hline $\begin{array}{l}10^{\prime \prime} \\
\Delta p\end{array}$ & $\begin{array}{c}330 \\
0.722 \\
\end{array}$ & $\begin{array}{c}546 \\
1.445\end{array}$ & $\begin{array}{c}792 \\
2.167\end{array}$ & $\begin{array}{l}1062 \\
2.167\end{array}$ & $\begin{array}{l}2129 \\
2.890\end{array}$ \\
\hline $\begin{array}{l}12^{\prime \prime} \\
\Delta p\end{array}$ & $\begin{array}{c}607 \\
1.445\end{array}$ & $\begin{array}{l}1005 \\
2.167\end{array}$ & $\begin{array}{l}1458 \\
2.890\end{array}$ & $\begin{array}{l}1955 \\
3.611\end{array}$ & $\begin{array}{l}2791 \\
4.334\end{array}$ \\
\hline
\end{tabular}

$\dot{W}_{\text {net }}=\dot{W}_{\text {comp }}+\dot{W}_{\text {ammonia tank }}=\dot{m}\left(h_{3}-h_{2}\right)+\dot{m}(1-x)\left(h_{2}-h_{1}\right)(25)$

In this equation, $x$ is the ratio of vapour mass to total refrigerant mass flow rate at the intermediate pressure of the cycle. The term $(1-x)$ refers to the liquid mass ratio of the



Fig. 3 - Transfer mechanism of ammonia between manifold system and storage tank 
cycle. However, excess coefficient of performance (COP) as another efficiency parameter can be calculated as a coefficient of performance. ${ }^{25}$

Therefore, the COP of this system can be determined as follows:

$$
\begin{aligned}
& \mathrm{COP}=\frac{\dot{Q}_{L}}{\dot{W}_{\text {net }}}=\frac{(1-x)\left(h_{1}-h_{3}\right)}{\left(h_{3}-h_{2}\right)+\dot{m}(1-x)\left(h_{2}-h_{1}\right)} \\
& h_{1}:\left(T_{2}-T_{1}\right) \\
& h_{2}:\left(T_{3}-T_{1}\right) \\
& h_{3}:\left(T_{3}-T_{2}\right) \\
& T_{1}=+5{ }^{\circ} \mathrm{C}, T_{2}=-33{ }^{\circ} \mathrm{C}, T_{3}=-9{ }^{\circ} \mathrm{C} \\
& m: 1 \mathrm{th}^{-1} \\
& x: 0.1 \\
& \mathrm{COP}=\frac{\dot{Q}_{L}}{\dot{W}_{\text {net }}}=-\frac{(1-x)\left(h_{1}-h_{3}\right)}{\left(h_{3}-h_{2}\right)+\dot{m}(1-x)\left(h_{2}-h_{1}\right)} \\
& \mathrm{COP}=\frac{(1-0.1)(-38-24)}{((24+14)+1(1-0.1)(-14+38))}=0.945
\end{aligned}
$$

The second efficiency or excessive COP can be calculated as follows: ${ }^{25}$

$$
\begin{gathered}
\mathrm{COP}=\frac{\dot{E} x_{Q}}{\dot{W}_{\text {net }}}=\frac{\dot{Q}_{L}\left(\frac{T_{0}}{T_{L}}-1\right)}{\dot{W}_{\text {comp }}+\dot{W}_{\text {tank }}} \\
\operatorname{COP}=\frac{(1-x)\left(h_{1}-h_{3}\right)\left(\frac{T_{0}}{T_{L}}-1\right)}{\left(h_{3}-h_{2}\right)+\dot{m}(1-x)\left(h_{2}-h_{1}\right)}=0.914
\end{gathered}
$$

However, since the work efficiency in terms of providing the cryogenic conditions with ammonia is found as 0.945 as a result of the exergy analysis, excessive COP calculation can be assumed as negligible.

\section{Conclusion}

During the transfer of anhydrous ammonia, the tendency of ammonia to evaporate continuously causes temperature changes in the transfer lines. Since these temperature changes cause volumetric differences in the transfer lines, they cause damage to the lines with the corrosive effect of ammonia. Therefore, material selection is an important issue in the design of transfer lines due to the cryogenic environment and corrosive properties. In order to prevent volumetric differences that may occur in transfer lines, creating loops along the line has been presented as a solution, and an exergy analysis of this system has been made and its thermodynamic results revealed. In this respect, with the exergy analysis made here, it can be concluded that the transfer process of ammonia, applying multi-stage compressors, and circulating in ammonia tanks and transfer lines, is realized with $94.5 \%$ efficiency. It can be stated that this result is a very good performance compared to the thermodynamic systems reported in the literature.

\section{List of abbreviations and symbols}

$$
\begin{aligned}
& \text { A - pipe cross-section area, } \mathrm{m}^{2} \\
& \mathrm{C}_{\text {total }} \text { - total cost, USD } \\
& \text { COP - coefficient of performance } \\
& \text { CRF - Capital Recovery Factor } \\
& \text { DF - depreciation factor } \\
& \text { D - pipe diameter, } \mathrm{m} \\
& D_{i, \text { opt }} \quad \text { - optimum pipe inner diameter, } \mathrm{m} \\
& f \quad-\text { Darcy-Weisbach friction coefficient } \\
& h_{\text {liq }} \quad \text { - enthalpy of liquid ammonia at the } \\
& \text { expansion valve inlet, } \mathrm{kJ} \mathrm{kg}^{-1} \\
& h_{\text {vap }} \quad \text { - enthalpy of ammonia at the evaporator outlet, } \mathrm{kJ} \mathrm{kg}^{-1} \\
& \text { L } \quad \text { - pipe length, } \mathrm{m} \\
& \dot{m} \quad-\text { mass flow rate, } \mathrm{kgs}^{-1} \\
& \Delta p \quad-\text { pressure loss due to friction in the pipe, } \mathrm{Pa} \text { or } \mathrm{Pa} \mathrm{m}^{-1} \\
& Q \quad \text { - volume flow, } \mathrm{m}^{3} \mathrm{~s}^{-1} \\
& \dot{Q} \quad-\text { heat flux, } \mathrm{W} \mathrm{m}^{-2} \\
& \dot{Q}_{L} \quad \text { - thermal change over unit ( } L \text { ) length, kJ } \\
& \text { Re } \quad-\text { Reynolds number } \\
& \text { tan - annual working time, } \mathrm{H} \\
& \text { - ratio of ammonia gasified/liqufied along the transfer } \\
& \text { line to the total amount of ammonia } \\
& \checkmark \quad \text { - average flow velocity, } \mathrm{m} \mathrm{s}^{-1} \\
& \dot{W} \quad \text { - work done in the process, kJ } \\
& q_{\mathrm{rl}} \quad \text { - amount of heat transfer along length } L \\
& \text { and diameter } r \\
& \delta \quad \text { - pipe outer/inner diameter ratio } \\
& \rho \quad-\text { fluid density, } \mathrm{kg} \mathrm{m}^{-3} \\
& v \quad-\text { kinematic viscosity, } \mathrm{m}^{2} \mathrm{~s}^{-1} \\
& \eta_{\mathrm{s}} \quad-\text { isentropic efficiency } \\
& \eta_{\mathrm{m}} \quad-\text { mechanical efficiency } \\
& \mu \quad-\text { dynamic viscosity, } \mathrm{kg} \mathrm{ms}^{-1}
\end{aligned}
$$

\section{Literatura \\ References}

1. A. D. Roach (Mapco Inc.), U.S. Patent No. 3,550,618. 29 Dec. 1970; D.E. (1970)

2. C. Hale, W. H. Lichtenberg, U. S. anhydrous ammonia distribution system in transition, Pritchard Corp, Cominco American Inc., vol. 28, 1988, pp. 76-90.

3. W. C. Leighty, J. H. Holbrook, Alternatives to electricity for transmission, firming storage, and supply integration for diverse, stranded, renewable energy resources: Gaseous hydrogen and anhydrous ammonia fuels via underground 
pipelines, Energy Proced. 29 (2012) 332-346, doi: https:// doi.org/10.1016/j.egypro.2012.09.040.

4. E. S. Sidney (Fenix \& Scisson, Inc), U.S. Patent No. 3,504,506. 7 Apr. 1970; O.K. (1970).

5. T. P Hignett, Transportation and Storage of Ammonia. In: Fertilizer Manual, Springer, Dordrecht, 1985, pp. 73-82, doi: https://doi.org/10.1007/978-94-017-1538-6_7.

6. D. G. Lippmann, Evaluation of risks related to the transport of anhydrous ammonia and their mitigation by localized small scale production, in: Proceedings of 2012 AIChE Ammonia Safety Symposium, 2012, page Paper 1b, Chicago, IL.

7. O. Elishav, B. M. Lis, A. Valera-Medina, G. S. Grader, Storage and Distribution of Ammonia, in: Techno-Economic Challenges of Green Ammonia as an Energy Vector, Academic Press, 2020, pp. 85-103, doi: https://doi.org/10.1016/ B978-0-12-820560-0.00005-9.

8. T. P. Whaley, G. M. Long, Pipelines, Othmer: Encyclopedia of Chemical Technology, The Interscience Encyclopedia, Inc., 2000, p. 710, New York, doi: https://doi.org/10.1002/0471 238961.1609160523080112.a01.

9. P. R. Scott, R. F. Scheuerman (Shell Oil Co.) U.S. Patent No. 3,480,024. 25 Nov. 1969; D.E. (1969).

10. C. Axel (Stamford, Conn.) U.S. Patent No. 2,938,360. 31 May 1960; N.Y. (1960).

11. J. E. Cottle (Phillips Petroleum Company) U.S. Patent No. 2,878,165. 17 Mar. 1959. D.E. (1959).

12. N. Gould, Neville, P. Weldon (The Minister of Agriculture for the State of New South Wales) U.S. Patent No. 6,003,534. 21 Dec. 1999. Dubbo, Australia (1999).

13. A. Alexandron, How to Protect Your Underground Ammonia Pipeline. Ammonia Technical Manual, Haifa Chemicals Ltd., 2008, pp. 239-246.

14. B. E. Scudder, (Subject to any disclaimer) U.S. Patent No. 7,036,441. 2 May 2006.I.L. (2006).

15. G. V. Rohleder, How high vapor pressure products are transported safely by pipeline, Pipeline Gas J. 5 (1975) 202.
16. G. D. Takalkar, R. R. Bhosale, N. A. Mali, S. S. Bhagwat, Energetic and exergetic performance of $\mathrm{NH}_{3}-\mathrm{H}_{2} \mathrm{O}$-based absorption refrigeration cycle: effect of operating factor, Int. J. Exergy 31 (2020) 352-369, doi: https://doi.org/10.1504/ IJEX.2020.107192.

17. A. Bhattad, J. Sarkar, P. Ghosh, Exergetic analysis of plate evaporator using hybrid nanofluids as secondary refrigerant for low-temperature applications, Int. J. Exergy 24 (2017) 1-20, doi: https://doi.org/10.1504/IJEX.2017.086857.

18. S. Gourmelon, R. Théry-Hétreux, P. Floquet, A systematic approach: combining process optimisation exergy analysis and energy recovery for a better efficiency of industrial processes, Int. J. Exergy 23 (2017) 298-329, doi: https://doi. org/10.1504/IJEX.2017.086169.

19. A. O. Gezerman, Industrial-scale purging of ammonia by using nitrogen before environmental discharge, Int. J. Ind. Chem. 7 (2016) 411-418, doi: https://doi.org/10.1007/ s40090-016-0096-6.

20. A. O. Gezerman, Exergy analysis and purging of an ammonia storage system, Int. J. Exergy 17 (2015) 335-351, doi: https://doi.org/10.1504/IJEX.2015.070502.

21. A. Ileri, S. C. Kesim, Soğutma Sistemleri için Optimum Boru Boyutlari, IV. Ulusal Tesisat Mühendisliği Kongresi ve Sergisi, Kasım 1999, Izmir.

22. A. O. Gezerman, B. D. Çorbacıoğlu, Off-Design Operation and Exergy Analysis of Multi-Stage Compressors, Int. J. Modern Eng. Sci. 2 (2013) 39-50.

23. A. O. Gezerman, B. D. Çorbacıoğlu, Triple Point Behavior of Ammonia under Compression, Res. J. Chem. Sci. 2 (2012) 58-60.

24. A. O. Gezerman, B. D. Çorbacıoğlu, Influence of Expansion Valves on Gasification in Ammonia Storage Systems, Res. J. Chem. Sci. 2 (2012) 1-7.

25. S. Seyam, Energy and Exergy Analysis of Refrigeration Systems in Low-temperature Technologies, Intechopen, 2019, pp. 1-20, London, UK, doi: https://doi.org/10.5772/intechopen.88862.

\section{SAŽETAK \\ Cjevovod za transport amonijaka u industrijskom mjerilu i analiza eksergije \\ Ahmet Ozan Gezerman}

Bezvodni amonijak je najčešće korištena sirovina u proizvodnji kemijskog gnojiva. U procesu proizvodnje gnojiva, tijekom transporta bezvodnog amonijaka, tlak i temperatura moraju se držati pod kontrolom. Transport i skladištenje bezvodnog amonijaka zahtijevaju otpornost na kriogene uvjete. Stoga je za transport amonijaka poželjno upotrebljavati materijale otporne na takve uvjete. U ovom je istraživanju analizirana kinetička energija transporta bezvodnog amonijaka pri kriogenim uvjetima $\left(-33^{\circ} \mathrm{C}\right)$ te raspravljena rješenja predložena s ciljem minimalizacije problema do kojih dolazi uslijed izloženosti kriogenim uvjetima, poput pucanja i korozije materijala upotrijebljenog za izradu sustava za transport i skladištenje.

Ključne riječi
Amonijak, kriogeni uvjeti, višestupnjeviti kompresor, razdjelnik

Toros Agri \& Industry, Research \&

Development Center, Mersin, Turska

Stručni rad

Prispjelo 15. prosinca 2020. Prihvaćeno 31. prosinca 2020. 